\title{
Periorbital Hyperpigmentation-Dark Circles under the Eyes; Treatment Suggestions and Combining Procedures
}

\author{
Alberto Goldman ${ }^{1}$, Mohamad Goldust ${ }^{2}$ and Uwe Wollina ${ }^{3, * \text { (D) }}$ \\ 1 Department of Plastic Surgery, Hospital São Lucas da PUCRS, Porto Alegre 90035-001, Brazil; \\ alberto@goldman.br.com \\ 2 Department of Dermatology, University Medical Center Mainz, 55131 Mainz, Germany; \\ mgoldust@uni-mainz.de \\ 3 Department of Dermatology and Allergology, Städtisches Klinikum Dresden, Academic Teaching Hospital, \\ Friedrichstrasse 41, 01067 Dresden, Germany \\ * Correspondence: Uwe.Wollina@klinikum-dresden.de
}

Citation: Goldman, A.; Goldust, M.; Wollina, U. Periorbital Hyperpigmentation-Dark Circles under the Eyes; Treatment Suggestions and Combining Procedures. Cosmetics 2021, 8, 26. https://doi.org/10.3390/cosmetics 8020026

Academic Editor: Francisco Solano

Received: 26 February 2021

Accepted: 23 March 2021

Published: 26 March 2021

Publisher's Note: MDPI stays neutral with regard to jurisdictional claims in published maps and institutional affiliations.

Copyright: () 2021 by the authors. Licensee MDPI, Basel, Switzerland. This article is an open access article distributed under the terms and conditions of the Creative Commons Attribution (CC BY) license (https:// creativecommons.org/licenses/by/ $4.0 /)$.

\begin{abstract}
Periorbital hyperpigmentation $(\mathrm{POH})$ is a frequent concern among both young and adult patients. The etiology is multifactorial with a genetic background. Prevalence is higher in darker skin types. It has been estimated as high as 30\% in a recent Indian study. Females are often more disappointed by $\mathrm{POH}$ than males. Treatment has to consider underlying pathologies and patients' needs. We present our treatment algorithm for POH. In this study, 74 patients with $\mathrm{POH}, 64$ females $(86.5 \%)$ and 10 males $(13.3 \%)$, were treated. Of these, 39 patients $(53 \%)$ had a family history of $\mathrm{POH}$. The age range of patients was 18-57 years (average: 36.1 years). In case of tear trough deformity, soft tissue augmentation was used by injection of hyaluronic acid gel, calcium hydroxylapatite, or autologous fat. Blepharoplasty with partial fat pad resection or repositioning via arcus marginalis release was used to correct severe orbital fat herniation and excess of the lower lid skin. Melanin hyperpigmentation of the skin was improved by sessions of Q-switched 1064 and 532 nm neodymiumdoped yttrium aluminum garnet (Nd:YAG) laser. Small vessels (capillaries and veins) were targeted by a $1064 \mathrm{~nm}$ long-pulsed Nd-YAG laser. Sessions of intense pulsed light (IPL) or $\mathrm{CO}_{2}$ fractional laser were employed to improve skin texture and fine lines. Topical hyaluronic acid-based formulations may be used as adjuvant self-treatment by patients. For pigmented and mixed-type $\mathrm{POH}$, ultraviolet light protection is recommended as a maintenance treatment. By the use of various technologies, treatment can be individually tailored.
\end{abstract}

Keywords: periorbital hyperpigmentation; pathogenesis; treatment; laser

\section{Introduction}

Periorbital hyperpigmentation $(\mathrm{POH})$ or dark circles under the eyes is a very frequent concern among both young and adult patients of any skin type. $\mathrm{POH}$ interferes with perceived age. We define $\mathrm{POH}$ as the occurrence of bilateral hyperchromatic macules and patches usually affecting the lower eyelids. This hyperpigmentation can also be present on the upper eyelids, malar region, eyebrows, and neighboring regions.

The etiology of POH is multifactorial. Volume loss and tear trough, skin laxity and translucent skin, prominent vasculature or blood stasis, excessive pigmentation, allergy, asthma, atopic dermatitis, and orbital adipose tissue prolapse are contributing factors in $\mathrm{POH}$ [1]. The combination of Dennie-Morgan fold and $\mathrm{POH}$ is highly suspicious for atopic dermatitis [2]. Atopic dermatitis is probably the most common dermatosis associated with $\mathrm{POH}$ [3]. Several medical drugs may cause $\mathrm{POH}$, such as prostaglandins or imatinib [4,5]. A cross-sectional study among Malaysian Chinese identified single nucleotid polymorphism in $p 53$ and vascular endothelial growth factor A (VEGFA) genes. They found an association of TA (tyrosine -adenosine) genotype in rs1437756379 of p53 to mixed vascular- 
pigmented POH and AC (adenosine-cytosine) genotype in rs1377053612 of VEGFA to atopic (pollinosis) phenotype [6]. Family history is often positive [7].

A common concept in society is that $\mathrm{POH}$ is a symptom of lack of sleep or fatigue, but this aspect is discussed as controversial [8,9]. Contact-free hyperspectral imaging identified melanin as the dominant chromophore while hemoglobin oxygen saturation was secondary. Participation of local microcirculation in the visual assessment of $\mathrm{POH}$ was also noted [7]. Kikuchi et al. (2013) used a contact spectrophotometer to study POH. Their data demonstrated that melanin content increased, while hemoglobin oxygen saturation ratio decreased locally in the $\mathrm{POH}$-affected skin [10]. $\mathrm{POH}$ can be classified according to causes and appearance [11] (Table 1). Huang et al. (2014) developed another classification that includes pigmented (brown), vascular (blue to purple), structural, and mixed-type. Mixed-type (78\%) and vascular-type (14\%) were the commonest subtypes in Taiwan [12]. In a Korean study of 100 patients with $\mathrm{POH}$, vascular-type (35\%) and mixed-type (54\%) dominated [13]. A Malaysian study identified the vascular type as the major one (51\%), while the pigmentary type was the least common with $6 \%$ [14]. A study from India reported constitutional $(51.5 \%)$ and post-inflammatory $(22.5 \%) \mathrm{POH}$ types as the commonest [8]. Ethnical and geographical factors might contribute to the variable presentation of $\mathrm{POH}$ subtypes. Grading of the severity of $\mathrm{POH}$ is given in Table 2.

Table 1. Classification of periorbital hyperpigmentation (POH) according to Ranu et al. (2011) [11].

\begin{tabular}{ccc}
\hline Constitutional & $\begin{array}{c}\text { - Patients show a curved band of brownish to black skin pigmentation on lower eyelids } \\
\text { approximating the shape of the orbital rim with frequent involvement of upper eyelids. }\end{array}$ \\
\hline Post-inflammatory & $\begin{array}{r}\text { Here, irregular patches of brownish or gray pigmentation can be found on the upper, lower, or } \\
\text { both eyelids with lichenification, and eczematous lesions in the surrounding areas. }\end{array}$ \\
Vascular & $\begin{array}{r}\text { Patients present with erythema predominantly involving the inner aspect of lower eyelids, } \\
\text { with prominent capillaries or telangiectasia, often with a thin translucent skin. There may be a } \\
\text { bluish discoloration of the lower eyelid and visible bluish veins. }\end{array}$ \\
\hline Shadow effect & $\begin{array}{r}\text { This type is mainly due to structural anatomical factors (e.g., overhanging tarsal muscle, eye } \\
\text { bags, or a deep tear trough). }\end{array}$ \\
Others & $\begin{array}{r}\text { - Such as internal disorders (e.g., anemia, hormonal disturbances, nutritional deficiencies), skin } \\
\text { disease (e.g., acanthosis nigricans, cutis laxa, nevus Ota, nevus Hori, erythema dyschromicum } \\
\text { perstans, fixed drug eruption), and drugs (latanoprost and bimatoprost eye drops). }\end{array}$ \\
\hline
\end{tabular}

Table 2. Severity grading of POH according to Sheth et al. (2014) [8].

\begin{tabular}{cc}
\hline Grade & Remarks \\
\hline 0 & Skin color not different from other facial skin areas \\
\hline 1 & Faint pigmentation of infraorbital folds \\
\hline 2 & More pronounced \\
\hline 3 & Deep dark color, all eyelids involved \\
\hline 4 & Grade 3 pigmentation spreading beyond the infraorbital fold \\
\hline
\end{tabular}

Epidemiological data on $\mathrm{POH}$ are scarce. In an Indian study, the prevalence was 30.8\%. A total of 200 patients with $\mathrm{POH}$ were analyzed; 81\% were females. The dominant age was 16 to 25 years. Of these patients, $63 \%$ had a positive family history, and $50 \%$ an iron deficiency anemia [8]. In a Brazilian study from Porto Alegre, $91 \%$ of $\mathrm{POH}$ patients were female. Females were unhappier with $\mathrm{POH}$ than males [9].

\section{Diagnosis}

Diagnosis is primarily clinical. Wood's lamp examination is useful to differentiate between epidermal or dermal pigmentation. If there is no accentuation of pigment, then $\mathrm{POH}$ is due to dermal melanin pigmentation or vascularity. If there is an accentuation of 
pigment, then it is due to superficial melanin pigmentation [12]. Skin biopsy with histology is rarely necessary for differential diagnosis [15]. Patch and prick tests are recommended for suspected allergies.

\section{Treatment}

The treatment of $\mathrm{POH}$ is dependent on the underlying etiology. There are topical, physical, and surgical treatment options. Among topical drugs and methods, sunscreens and peels are widely used [16,17]. Tretinoin, vitamin C, arbutin, and azelaic acid are known to reduce melanin pigmentation [18-22].

Laser treatments have been used for the treatment of $\mathrm{POH}$ as well, including longpulsed and picosecond laser types for pigmentations, tattoo removal, and vascular lesions [22-26]. In addition, topical treatment may be combined with lasers to achieve a better outcome [1,27]. Tear trough-associated $\mathrm{POH}$ can be corrected by dermal fillers [28].

\section{Our Patients and Concept}

In this study, we treated 74 patients with $\mathrm{POH}, 64$ females (86.5\%) and 10 males $(13.3 \%)$. Of these, 39 patients (53\%) had a family history of $\mathrm{POH}$. Their age range was $18-57$ years (average: 36.1 years).

Inclusion criteria were age $>18$ years, no untreated comorbidities, no infections in the area to be treated, and informed patient consent. Exclusion criteria were age $<18$ years, pregnancy or lactation, local or systemic infections, missing informed consent, unwillingness for follow-up, and drug-induced $\mathrm{POH}$ in case the drug has to be continued for medical reasons.

The first step in treatment is based on a careful medical history and clinical examination to identify the components of $\mathrm{POH}$ and includes:

- Presence, intensity, and extension of melanin.

- Presence of small blood vessels under the skin.

- Presence of eyelids fat pads.

- Presence of tear trough deformity.

- Presence of skin excess and skin texture changes (lines and wrinkles).

The treatment has to focus on the underlying pathology and components of $\mathrm{POH}$. We considered comorbidities that could interfere with treatment selection, such as atopic dermatitis. In this case, dermatological treatment of the inflammatory dermatosis should precede treatment of $\mathrm{POH}$.Tear trough deformity: For tear trough deformity, soft tissue augmentation is used. Injection of hyaluronic acid gel, calcium hydroxylapatite, or autologous fat has been reported [29,30]. In patients with more pronounced deformities, severe orbital fat herniation and excess of the lower eyelid blepharoplasty with partial fat pad resection or repositioning via arcus marginalis release is performed [31-35].

In our experience, fat injection is the most efficient option to correct this concave deformity of the orbital fat. The density and consistency of the fat provide a natural appearance.

Hyperpigmentation of the skin due to the presence of melanin: We performed several sessions of Q-switched $1064 \mathrm{~nm}$ and $532 \mathrm{~nm}$ neodymium-doped yttrium aluminum garnet (Nd:YAG) laser. The wavelength selection depends on the color of hyperpigmented areas (brown, red, or blue). The following laser parameters were used: pulse width of $2 \mathrm{msec}$, pulse repetition rate between 0.5 and $3 \mathrm{~Hz}$, and fluency ranged from 4 to $16 \mathrm{~J} / \mathrm{cm}^{2}$. The spot size diameter was $4 \mathrm{~mm}$. By this laser technique, high energy is released in a very short period of time with leads to melanin fragmentation, allowing phagocytosis. Brightening of skin is the consequence.

Small vessels (capillaries and veins): In the case of vascular $\mathrm{POH}$, we preferred treatment with long-pulsed Nd-YAG laser $1064 \mathrm{~nm}$. On average, two or three sessions were performed every 3 or 4 weeks. The fluence ranged from 100 to $150 \mathrm{~J} / \mathrm{cm}^{2}$ with a 2.5 or $4.0 \mathrm{~mm}$ spot size. The pulse width varied from $3 \mathrm{msec}$ to $15 \mathrm{msec}$ [36].

Skin texture: To improve skin texture and address fine lines, sessions of intense pulsed light (IPL) or $\mathrm{CO}_{2}$ fractional laser were employed. In this case, the laser was preferred for 
deeper lines. Both IPL and $\mathrm{CO}_{2}$ laser are capable of improving skin quality and induce neo-collagenesis $[37,38]$. Topical hyaluronic acid-based formulations can be recommended as adjuvant self-treatment by patients $[39,40]$.

Protection from ultraviolet (UV) light is essential for post-laser therapy. For pigmented and mixed-type $\mathrm{POH}, \mathrm{UV}$ protection is also recommended as a maintenance treatment [41].

\section{Results}

Patient characteristics can be seen in Table 3. The treatment was well tolerated. Adverse events were mild and temporary. The main frequent events were ecchymosis and edema. Neither burn nor vascular problems or scarring were observed. There was neither significant pain nor discomfort after treatment. The major outcome of treatment was an improvement of $\mathrm{POH}$. Most patients also achieved better skin texture and appearance (Figures 1-5). The patients' evaluation was excellent in 26 patients $(35.1 \%)$, good in 36 patients $(48.6 \%)$, fair in 9 patients $(12.1 \%)$, and poor in 3 patients $(4.0 \%)$. Of all patients treated, $83.7 \%$ reported a good or excellent outcome (Table 4). All patients with vascular or post-inflammatory $\mathrm{POH}$ achieved a good or better result, while constitutional $\mathrm{POH}$ was the dominant subtype in patients with poor and fair outcomes.

Table 3. Characteristics of patients with periorbital hyperpigmentation treated with lasers and combined procedures.

\begin{tabular}{cc}
\hline No. of Subjects & 74 \\
\hline Average age (yrs) & 36.1 (range, $18-57)$ \\
\hline Female & $64(86.5 \%)$ \\
\hline Male & $10(13.3 \%)$ \\
\hline Average time of condition $(\mathrm{yrs})$ & $3.8($ range, $1-30)$ \\
\hline Follow-up & 6 to 32 months \\
\hline
\end{tabular}

Table 4. Improvement of periorbital hyperpigmentation aspect according to patient's assessment.

\begin{tabular}{cc}
\hline Improvement & $\mathbf{n ~ ( \% )}$ \\
\hline Poor (no improvement) & $3(4.0 \%)$ \\
\hline Fair (limited improvement) & $9(12.1 \%)$ \\
\hline Good (significant improvement) & $36(48.6 \%)$ \\
\hline Excellent (market improvement) & $26(35.1 \%)$ \\
\hline Total & $74(100 \%)$
\end{tabular}

Classification based on the percentage of periorbital hyperpigmentation improvement: poor (improvement from $0 \%$ to $25 \%$ ), fair ( $26 \%$ to $50 \%$ ), good ( $51 \%$ to $75 \%$ ), and excellent $(>75 \%)$. 


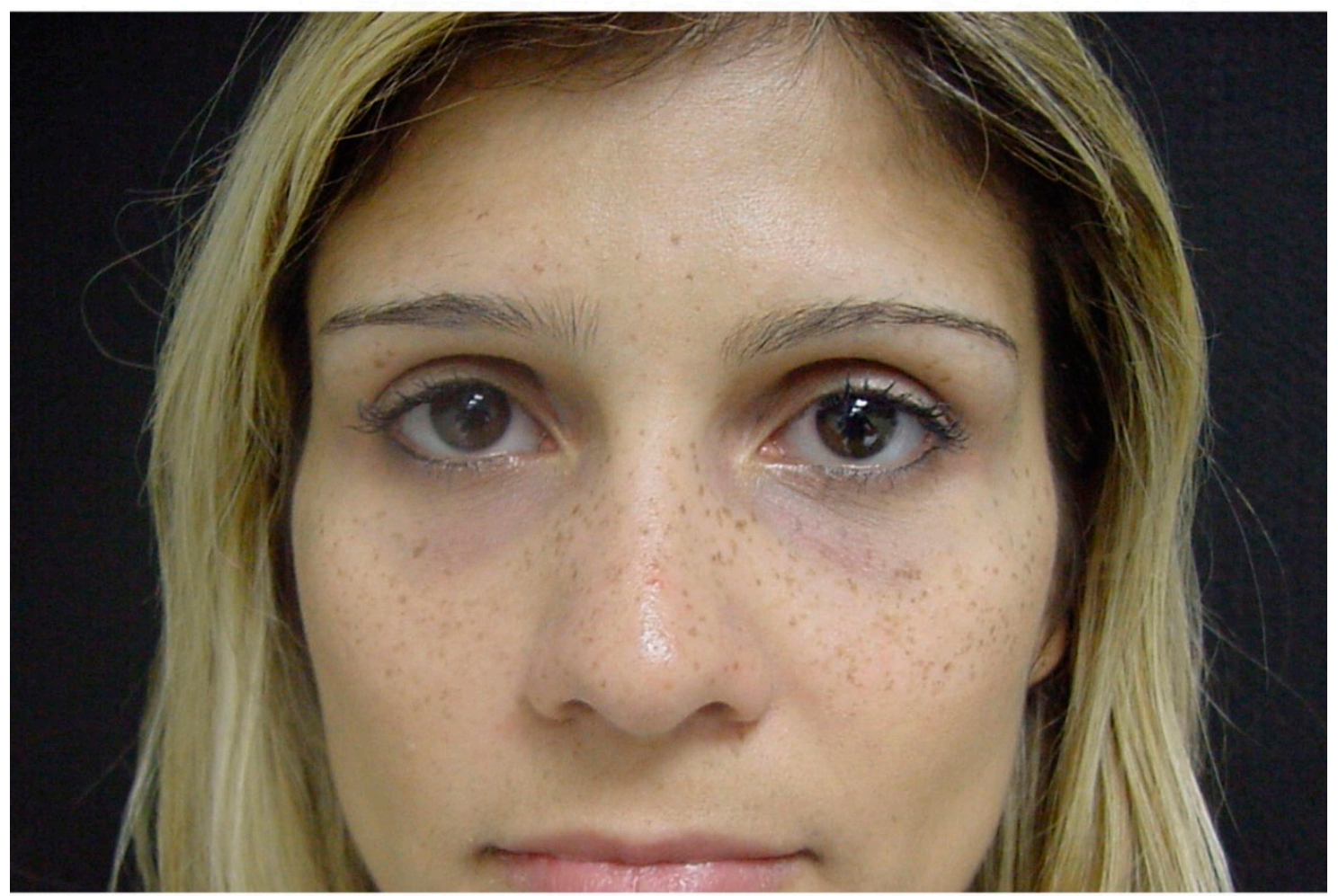

(a)

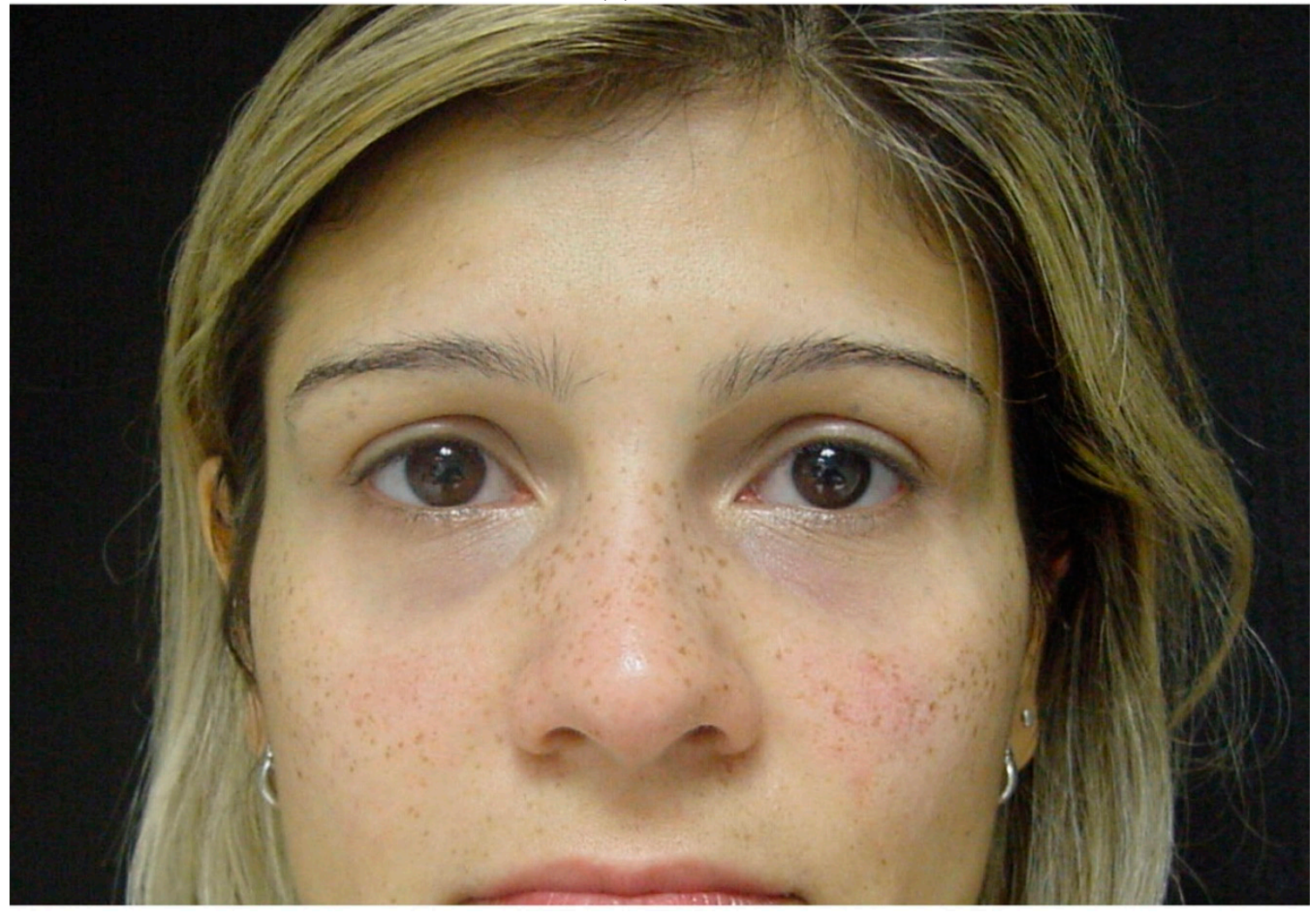

(b)

Figure 1. (a) - 31-year-old patient. Dark circles and freckles under the eyes. (b) - Result after two sessions of $1064 \mathrm{~nm}$ Q-Switched Nd-YAG laser and IPL. Improvement of POH and freckles. 


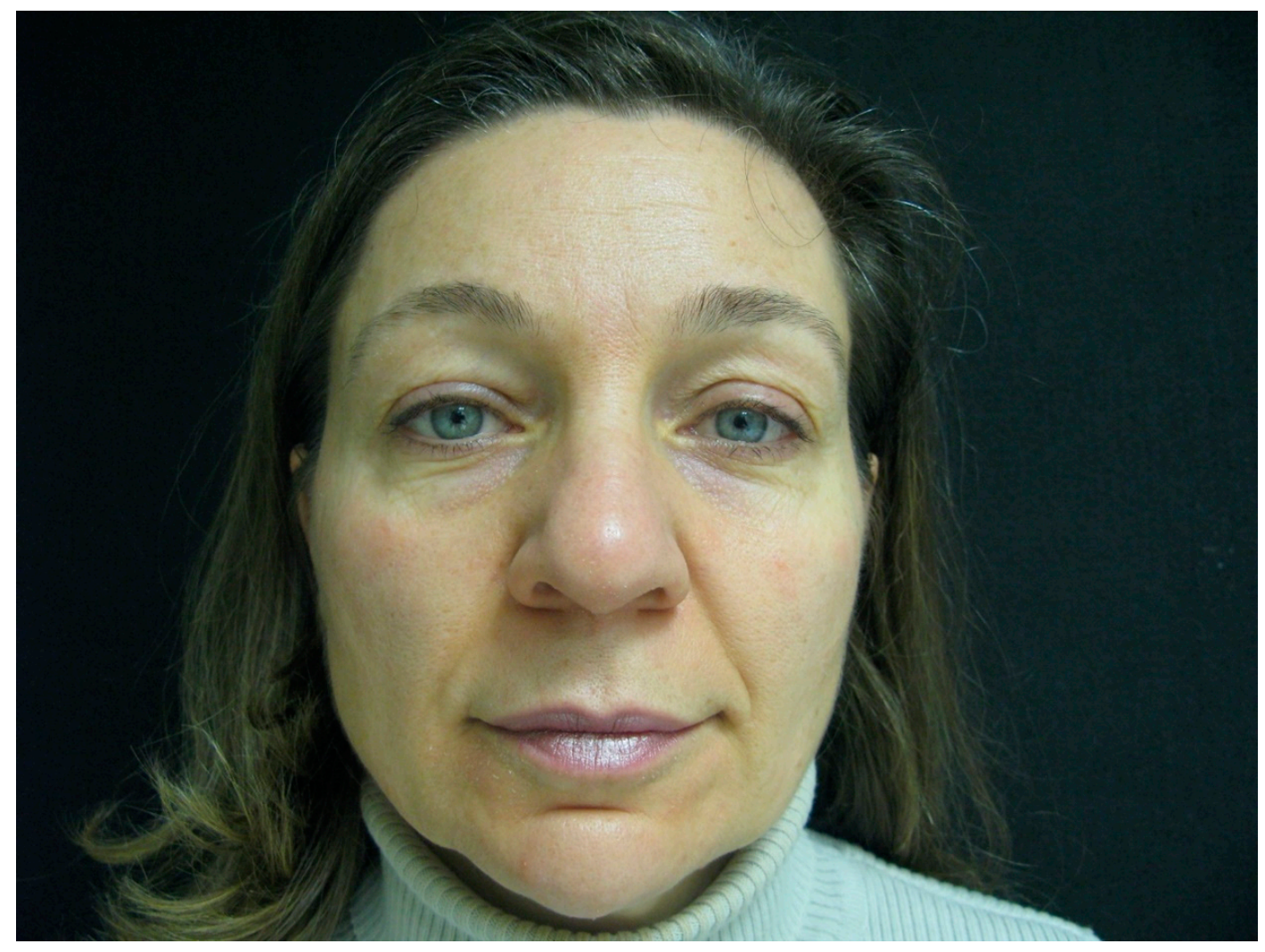

(a)

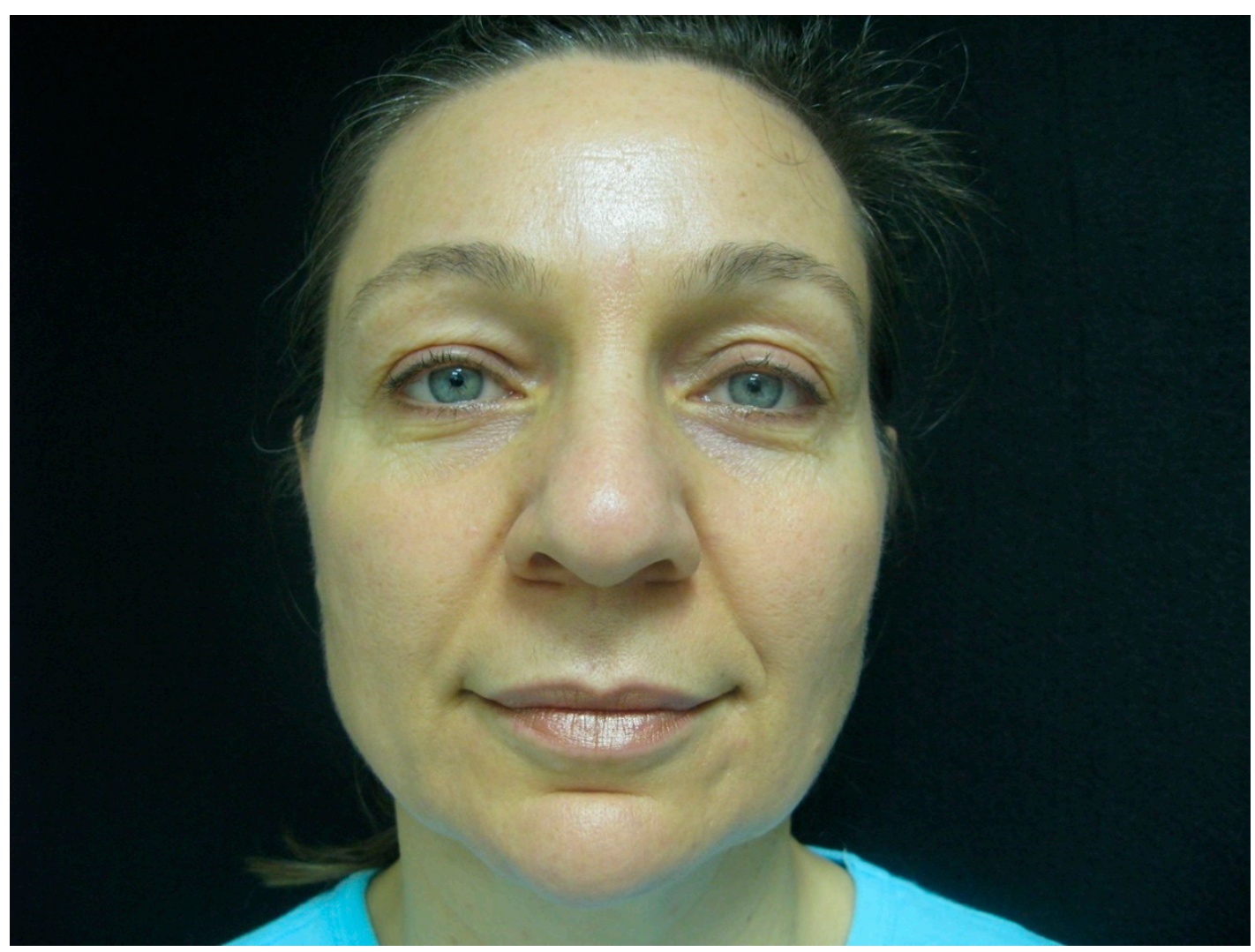

(b)

Figure 2. (a) - 48-year-old patient with POH. (b) -Improvement after two sessions of 1064 nm Q-Switched Nd-YAG laser. 


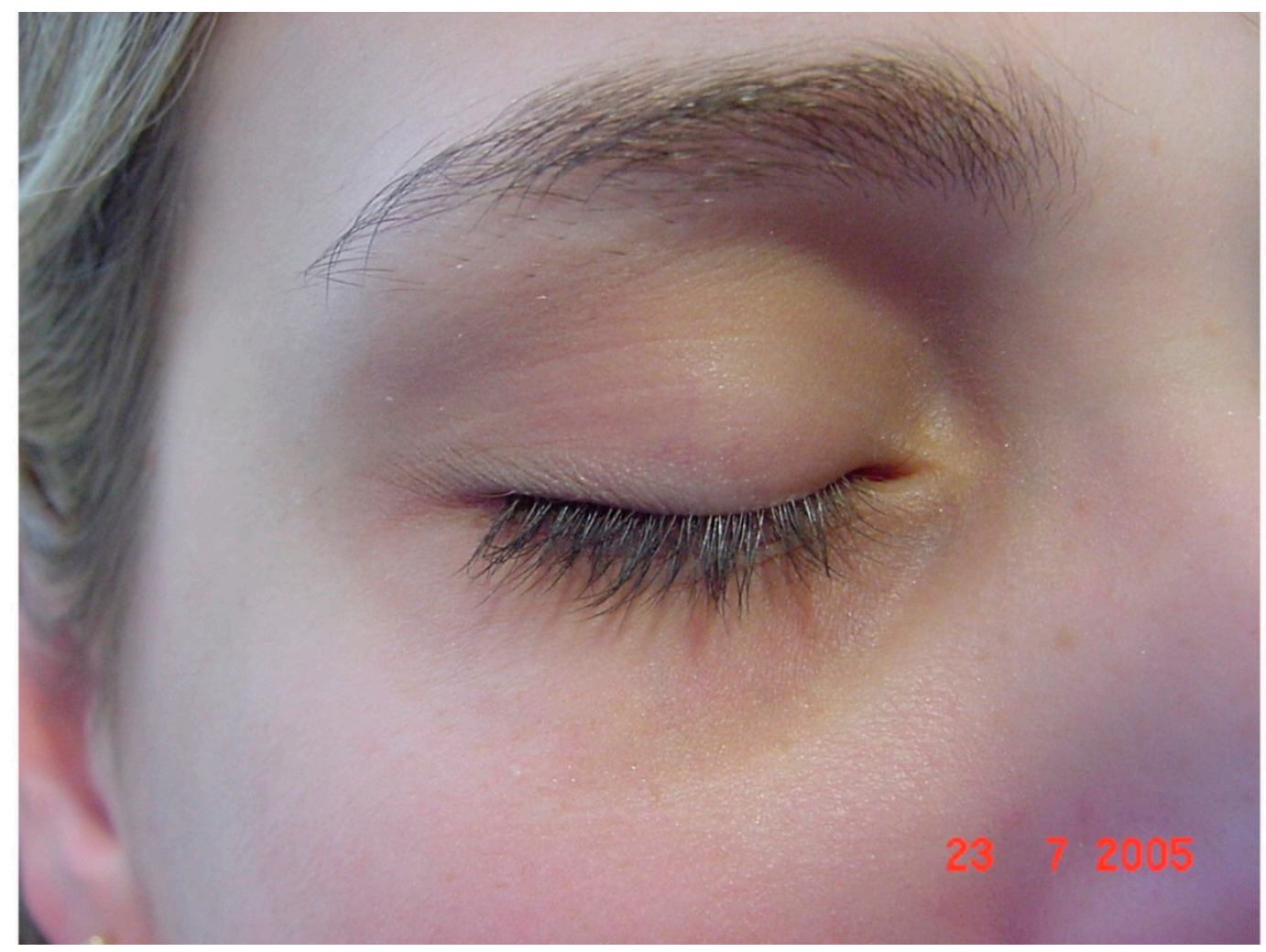

(a)

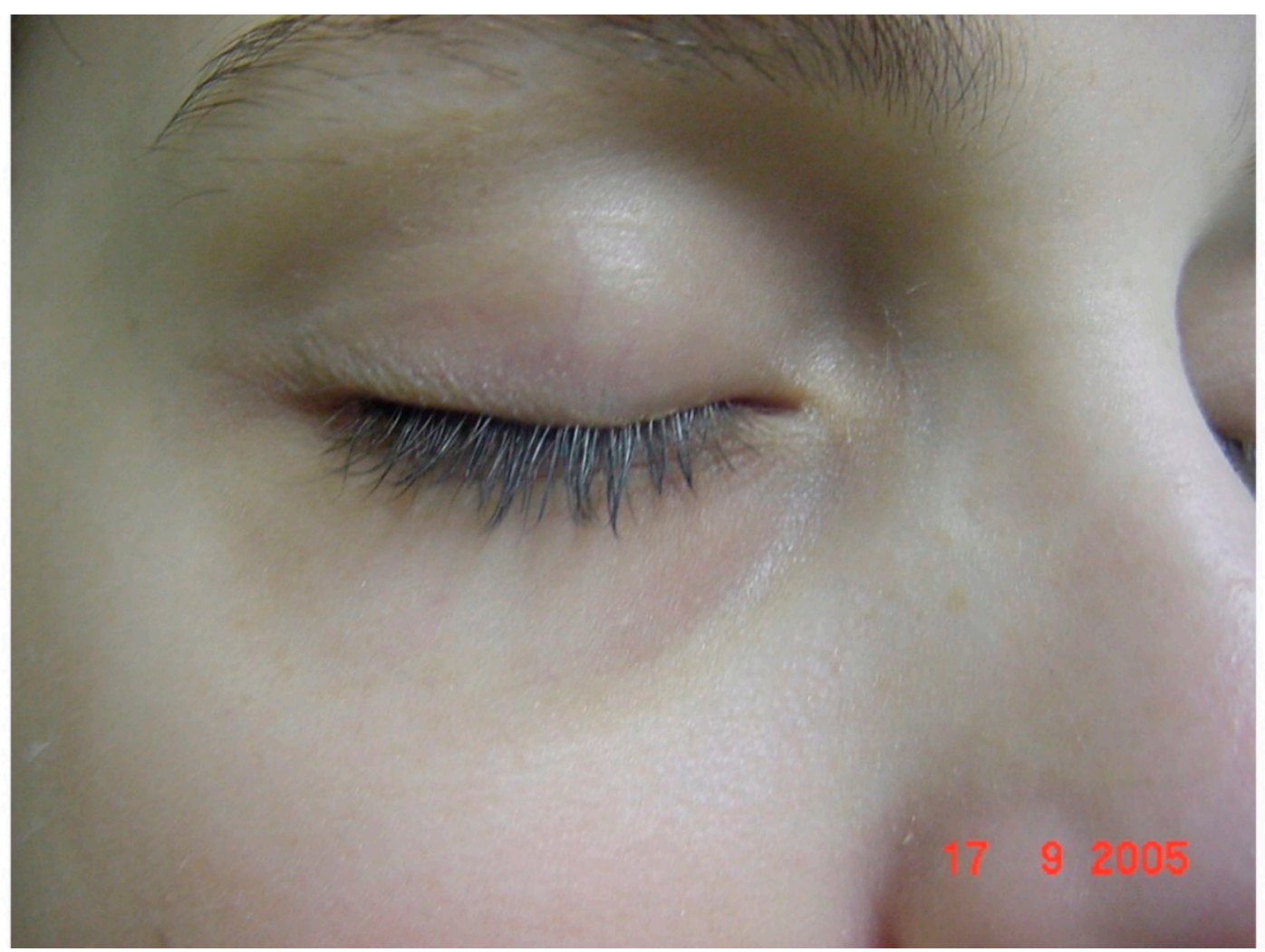

(b)

Figure 3. (a) - 19-year-old patient. Chronic treatment of asthma. Hyperpigmentation in upper and lower eyelids. (b)— Result after two sessions of $1064 \mathrm{~nm}$ Q-Switched Nd-YAG laser and one session of long pulsed $1064 \mathrm{~nm}$ Nd-YAG laser. 


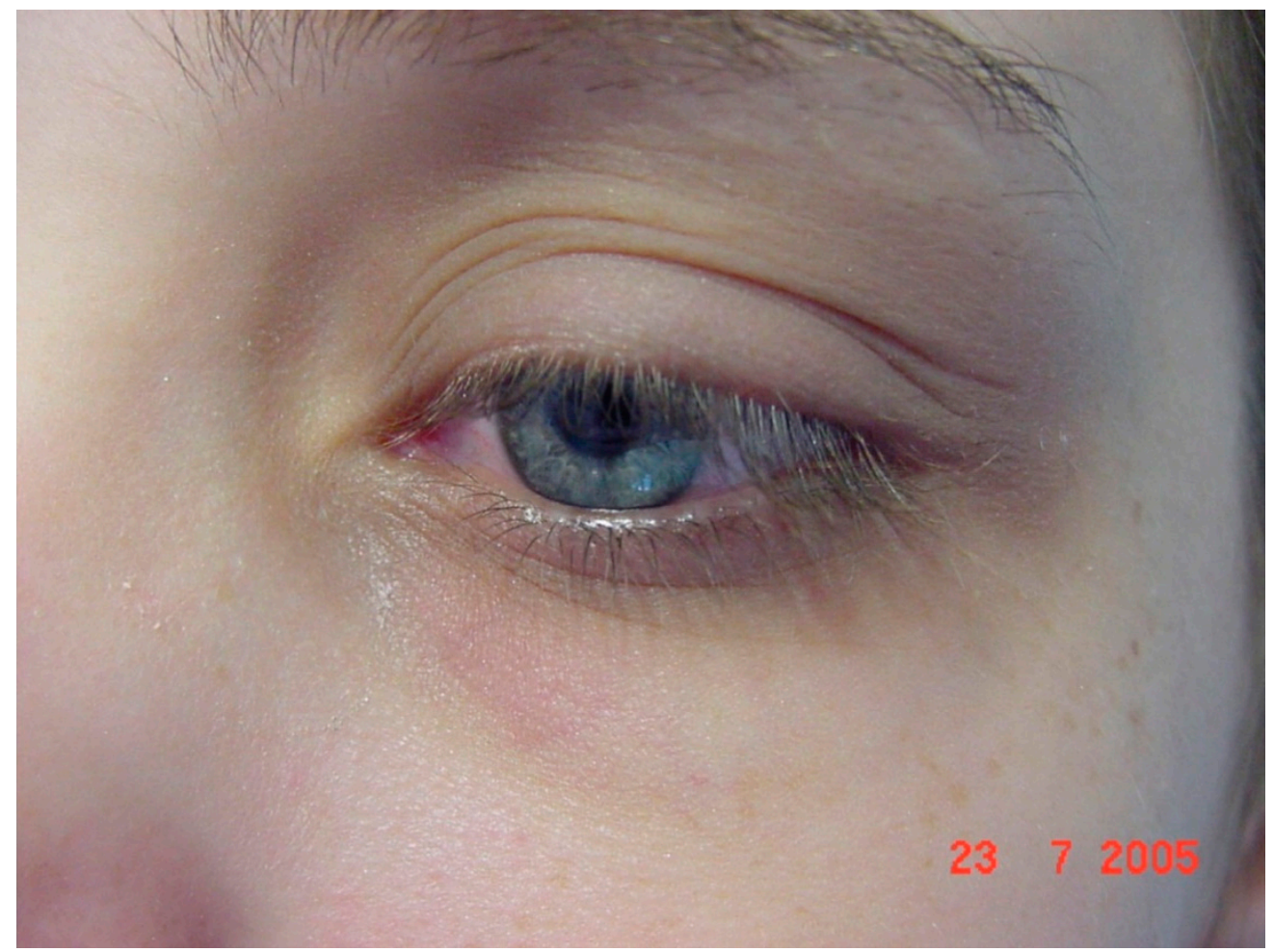

(a)

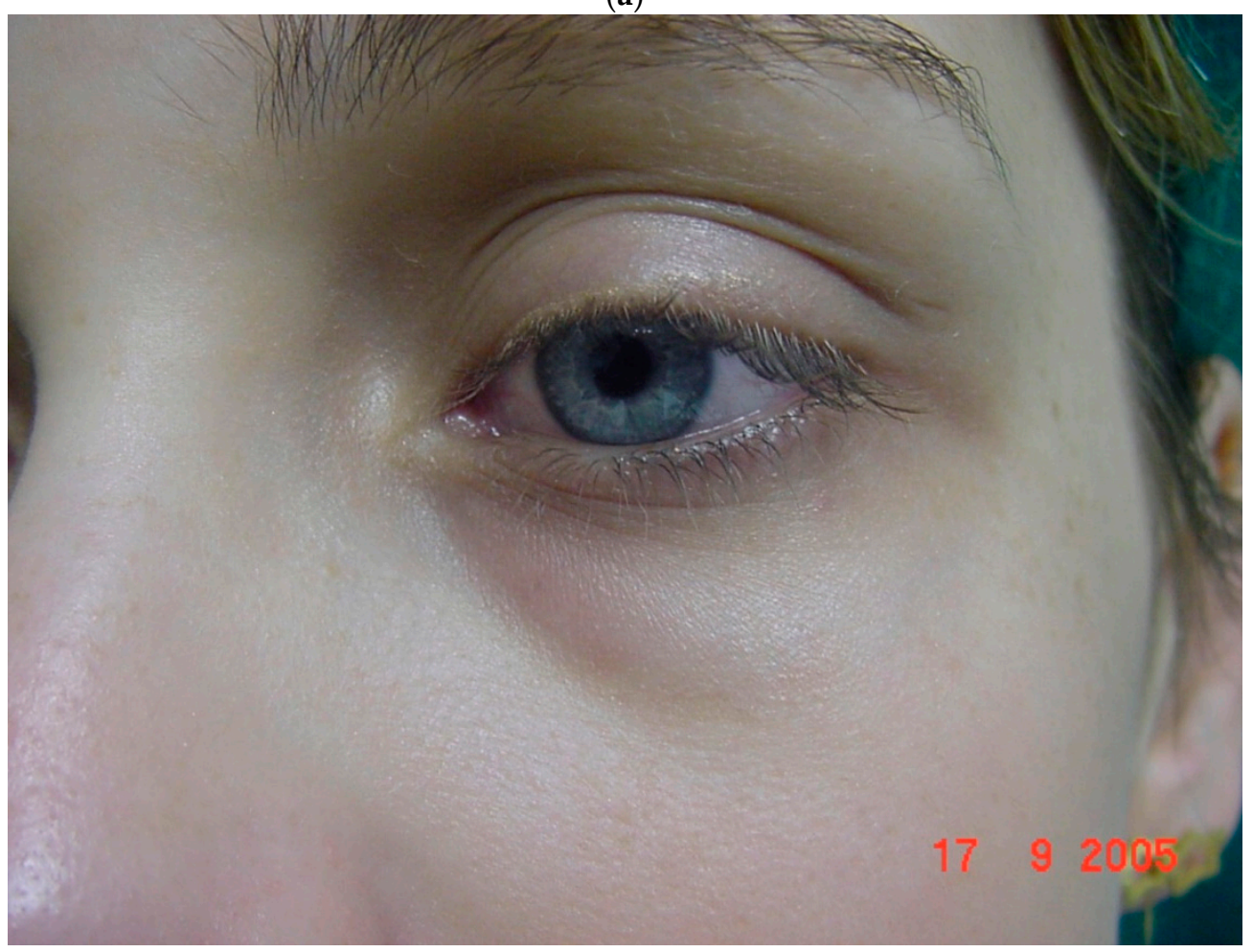

(b)

Figure 4. (a)-Same patient as in Figure 3. (b) - Improvement of the pigmentation, less edema and diminished show of small blood vessels after laser and IPL treatment. 


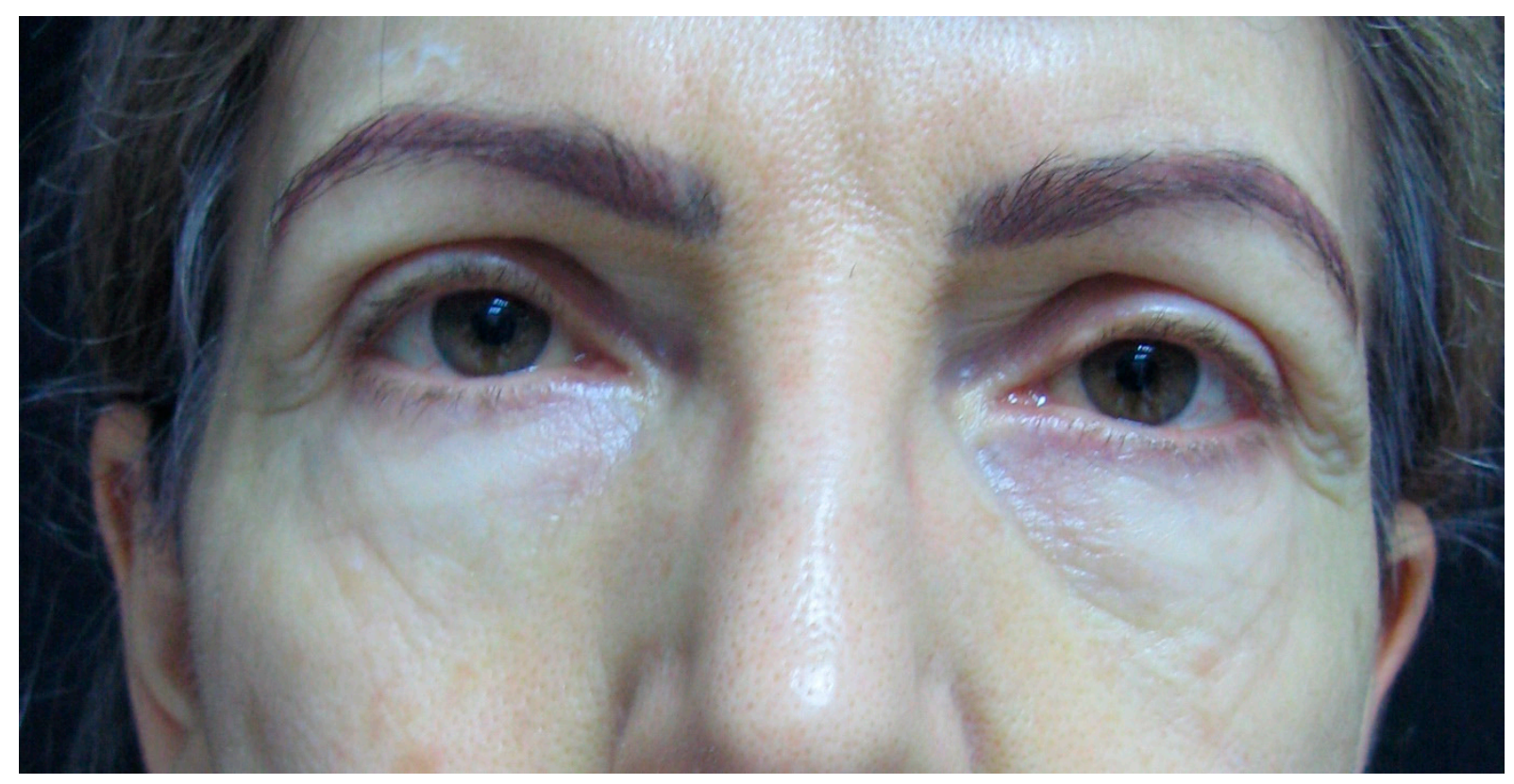

(a)

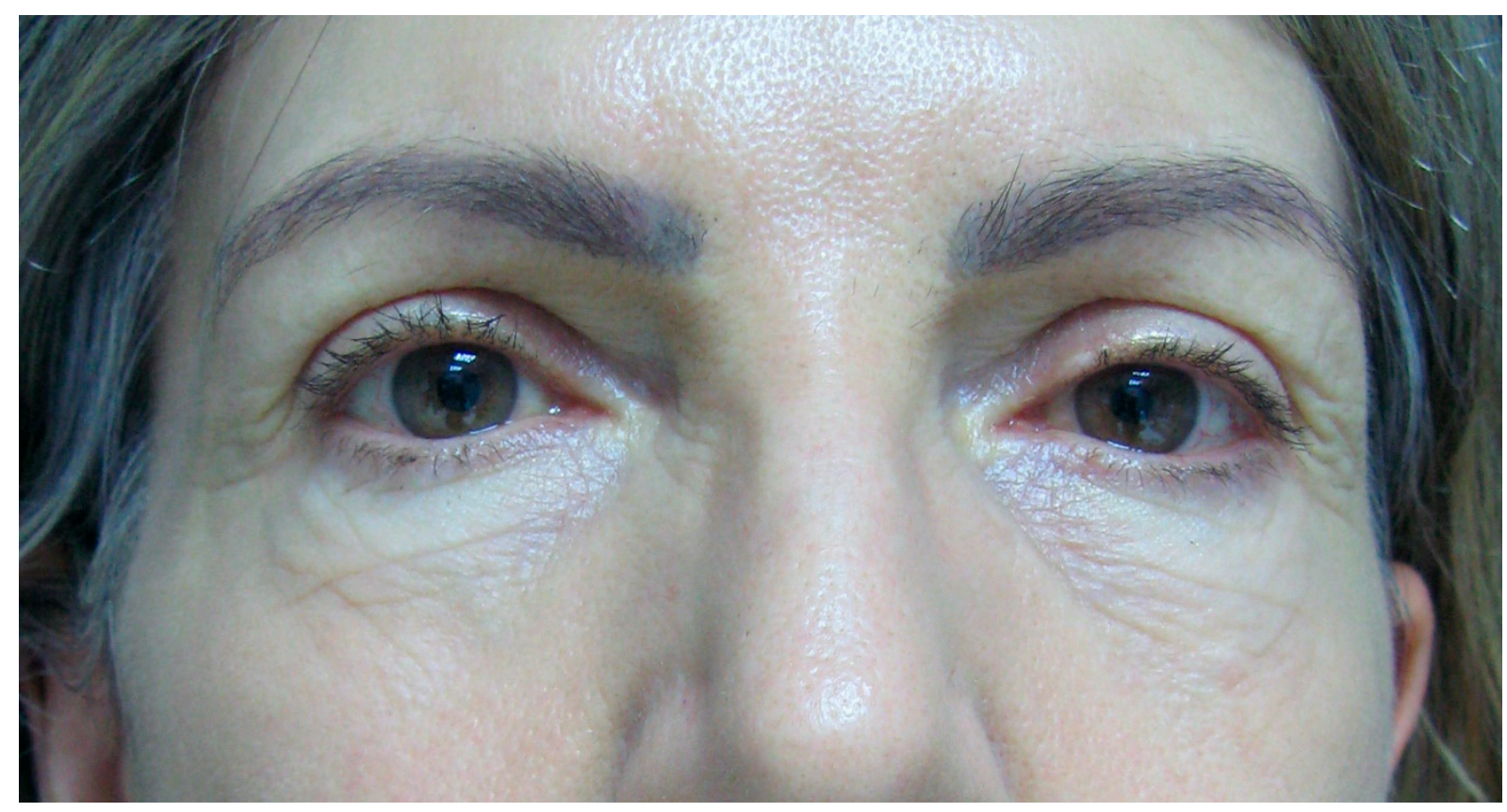

(b)

Figure 5. (a) - 59-year-old female patient. Hypertrophy of the fat pads on the lower both lower eyelids. Hyperpigmentation and tear through deformity on the lower left eyelid. (b)-Improvement of the pigmentation after two of sessions of Q-switched $1064 \mathrm{~nm}$. Improvement of tear through deformity with hyaluronic acid injection. Fat pad hypertrophy treated with transconjunctival blepharoplasty.

\section{Discussion}

$\mathrm{POH}$ is a multifactorial condition with esthetic importance and quality of life issues. $\mathrm{POH}$ results in a tired and exhausted appearance. It may be associated with an underlying pathology such as contact allergy or pollinosis, medical drug use, and sun exposure. Genetic predisposition is reported in about a third of patients [41]. 
Treatment is dependent upon causative factors, lifestyle, comorbidities, skin phototype, and resources. A systematic review considered laser therapy appropriate for pigmented and vascular $\mathrm{POH}$, while dermal fillers and autologous fat transfer were most effective in case of volume loss. Excessive skin laxity is addressed by blepharoplasty. In contrast, topical treatment with creams and peels has only a moderate effect on pigmented $\mathrm{POH}[26]$.

We reported on our experience with $\mathrm{POH}$ using lasers, surgery, and fillers as primary tools. These procedures have a short downtime and are minimally invasive. Satisfying esthetic results can be achieved, as illustrated by our clinical cases. We recommend UV protection in combination with skincare as maintenance therapy in pigmented and mixedtype $\mathrm{POH}[42]$.

\section{Conclusions}

$\mathrm{POH}$ is a multifactorial condition. An accurate diagnosis is fundamental to achieve a good, safe, and effective treatment result. Different laser sources, fillers, fat injection, or surgery can be used as a monotherapy or in combination to improve this condition. This allows tailoring the treatment according to underlying pathologies and patients' needs [1].

Author Contributions: Conceptualization, A.G. and U.W.; formal analysis, A.G., M.G., and U.W.; investigation, A.G.; methodology, A.G.; supervision, U.W.; validation, M.G.; writing—original draft, A.G.; writing-review and editing, A.G., M.G., and U.W. All authors have read and agreed to the published version of the manuscript.

Funding: This study received no external funding.

Institutional Review Board Statement: Not applicable.

Informed Consent Statement: Informed consent was obtained from all patients involved in this study.

Data Availability Statement: Files are stored at the Hospital in Porto Alegre/RS, Brazil.

Conflicts of Interest: The authors declare no conflict of interest.

\section{References}

1. Friedmann, D.P.; Goldman, M.P. Dark circles: Etiology and management options. Clin. Plast. Surg. 2015, 42, 33-50. [CrossRef]

2. Blanc, S.; Bourrier, T.; Albertini, M.; Chiaverini, C.; Giovannini-Chami, L. Dennie-Morgan fold plus dark circles: Suspect atopy at first sight. J. Pediatr. 2015, 166, 1541. [CrossRef] [PubMed]

3. Nettis, E.; Ferrucci, S.M.; Ortoncelli, M.; Pellacani, G.; Foti, C.; Di Leo, E.; Patruno, C.; Rongioletti, F.; Argenziano, G.; Macchia, L.; et al. Use of dupilumab for 543 adult patients with moderate-to-severe atopic dermatitis: A multicenter, retrospective study. $J$. Investig. Allergol. Clin. Immunol. 2020. [CrossRef] [PubMed]

4. Oogi, S.; Nakakura, S.; Terao, E.; Fujisawa, Y.; Tabuchi, H.; Kiuchi, Y. One-year follow-up study of changes in prostaglandinassociated periorbital syndrome after switch from conventional prostaglandin f2alfa to omidenepag isopropyl. Cureus 2020, 12, e10064. [CrossRef] [PubMed]

5. Vinay, K.; Yanamandra, U.; Dogra, S.; Handa, S.; Suri, V.; Kumari, S.; Khadwal, A.; Prakash, G.; Lad, D.; Varma, S.; et al. Long-term mucocutaneous adverse effects of imatinib in Indian chronic myeloid leukemia patients. Int. J. Dermatol. 2018, 57, 332-338. [CrossRef]

6. Amini, F.; Thazin Oo, N.M.; Okechukwu, P.N.; Seghayat, M.S.; Ng, E.S.C. Polymorphisms in P53 and VEGFA genes in different subtypes of periorbital hyperpigmentation in a Malaysian Chinese population. Australas J. Dermatol. 2019, 60, e99-e104. [CrossRef]

7. Matsui, M.S.; Schalka, S.; Vanderover, G.; Fthenakis, C.G.; Christopher, J.; Bombarda, P.C.; Bueno, J.R.; Viscomi, B.L.; Bombarda Júnior, M.S. Physiological and lifestyle factors contributing to risk and severity of peri-orbital dark circles in the Brazilian population. An. Bras. Dermatol. 2015, 90, 494-503. [CrossRef]

8. Sheth, P.B.; Shah, H.A.; Dave, J.N. Periorbital hyperpigmentation: A study of its prevalence, common causative factors and its association with personal habits and other disorders. Indian J. Dermatol. 2014, 59, 151-157. [CrossRef]

9. Barone, C.R.; Boza, J.C.; Machado, P.G.; Cestari, T.F. Association between clinical characteristics, quality of life, and sleep quality in patients with periorbital hyperchromia. J. Cosmet. Dermatol. 2018. [CrossRef]

10. Kikuchi, K.; Masuda, Y.; Hirao, T. Imaging of hemoglobin oxygen saturation ratio in the face by spectral camera and its application to evaluate dark circles. Skin Res. Technol. 2013, 19, 499-507. [CrossRef]

11. Ranu, H.; Thng, S.; Goh, B.K.; Burger, A.; Goh, C.L. Periorbital hyperpigmentation in Asians: An epidemiologic study and a proposed classification. Dermatol. Surg. 2011, 37, 1297-1303. [CrossRef] [PubMed] 
12. Huang, Y.L.; Chang, S.L.; Ma, L.; Lee, M.C.; Hu, S. Clinical analysis and classification of dark eye circle. Int. J. Dermatol. 2014, 53, 164-170. [CrossRef] [PubMed]

13. Park, S.R.; Kim, H.J.; Park, H.K.; Kim, J.Y.; Kim, N.S.; Byun, K.S.; Moon, T.K.; Byun, J.W.; Moon, J.H.; Choi, G.S. Classification by causes of dark circles and appropriate evaluation method of dark circles. Skin Res. Technol. 2016, 22, 276-283. [CrossRef] [PubMed]

14. Fatin, A.M.; Mathana Sundram, T.K.; Tan, S.S.E.; Seghayat, M.S.; Lee, C.K.; Rehman, N.; Tan, C.K. Classification and characteristics of periorbital hyperpigmentation. Skin Res. Technol. 2020, 26, 564-570. [CrossRef] [PubMed]

15. Graziosi, A.C.; Quaresma, M.R.; Michalany, N.S.; Ferreira, L.M. Cutaneous idiopathic hyperchromia of the orbital region (CIHOR): A histopathological study. Aesthetic Plast. Surg. 2013, 37, 434-438. [CrossRef] [PubMed]

16. Ranjan, R.; Sarkar, R.; Garg, V.K.; Gupta, T. A comparative study of two modalities, $4 \%$ hydroquinone versus $30 \%$ salicylic acid in periorbital hyperpigmentation and assessment of quality of life before and after treatment. Indian J. Dermatol. 2016, 61, 413-417. [CrossRef]

17. Vavouli, C.; Katsambas, A.; Gregoriou, S.; Teodor, A.; Salavastru, C.; Alexandru, A.; Kontochristopoulos, G. Chemical peeling with trichloroacetic acid and lactic acid for infraorbital dark circles. J. Cosmet Dermatol. 2013, 12, 204-209. [CrossRef]

18. Chan, R.; Park, K.C.; Lee, M.H.; Lee, E.S.; Chang, S.E.; Leow, Y.H.; Tay, Y.K.; Legarda-Montinola, F.; Tsai, R.Y.; Tsai, T.H.; et al. A randomized controlled trial of the efficacy and safety of a fixed triple combination (fluocinolone acetonide $0.01 \%$, hydroquinone $4 \%$, tretinoin $0.05 \%$ ) compared with hydroquinone $4 \%$ cream in Asian patients with moderate to severe melasma. Br. J. Dermatol. 2008, 159, 697-703. [CrossRef]

19. Ertam, I.; Mutlu, B.; Unal, I.; Alper, S.; Kivçak, B.; Ozer, O. Efficiency of ellagic acid and arbutin in melasma: A randomized, prospective, open-label study. J. Dermatol. 2008, 35, 570-574. [CrossRef]

20. Ohshima, H.; Mizukoshi, K.; Oyobikawa, M.; Matsumoto, K.; Takiwaki, H.; Kanto, H.; Itoh, M. Effects of vitamin C on dark circles of the lower eyelids: Quantitative evaluation using image analysis and echogram. Skin Res. Technol. 2009, 15, 214-217. [CrossRef]

21. Ellabban, N.F.; Eyada, M.; Nada, H.; Kamel, N. Efficacy and tolerability of using platelet-rich plasma versus chemical peeling in periorbital hyperpigmentation. J. Cosmet. Dermatol. 2019, 18, 1680-1685. [CrossRef] [PubMed]

22. Dayal, S.; Sangal, B.; Sahu, P. Ferulic acid 12\% peel: An innovative peel for constitutional type of periorbital melanosis-Comparing clinical efficacy and safety with $20 \%$ glycolic peel and $15 \%$ lactic peel. J. Cosmet. Dermatol. 2020, 19, 2342-2348. [CrossRef] [PubMed]

23. Lowe, N.J.; Wieder, J.M.; Shorr, N.; Boxrud, C.; Saucer, D.; Chalet, M. Infraorbital pigmented skin. Preliminary observations of laser therapy. Dermatol. Surg. 1995, 21, 767-770. [CrossRef] [PubMed]

24. Chen, D.L.; Cohen, J.L. Treatment of periorbital veins with long-pulse Nd:YAG laser. J. Drugs Dermatol. 2015, 14, 1360-1362. [PubMed]

25. Vanaman Wilson, M.J.; Jones, I.T.; Bolton, J.; Larsen, L.; Wu, D.C.; Goldman, M.P. Prospective studies of the efficacy and safety of the picosecond 755, 1,064, and $532 \mathrm{~nm}$ lasers for the treatment of infraorbital dark circles. Lasers Surg Med. 2018, 50, 45-50. [CrossRef] [PubMed]

26. Del Duca, E.; Zingoni, T.; Bennardo, L.; Di Raimondo, C.; Garofalo, V.; Sannino, M.; Petrini, N.; Cannarozzo, G.; Bianchi, L.; Nisticò, S.P. Long-term follow-up for Q-switched Nd:YAG treatment of Nevus of Ota: Are high number of treatments really required? A case report. Photobiomodul. Photomed. Laser Surg. 2021, 39, 137-140. [CrossRef]

27. Michelle, L.; Pouldar Foulad, D.; Ekelem, C.; Saedi, N.; Mesinkovska, N.A. Treatments of periorbital hyperpigmentation: A systematic review. Dermatol. Surg. 2021, 47, 70-74. [CrossRef]

28. Momosawa, A.; Kurita, M.; Ozaki, M.; Miyamoto, S.; Kobayashi, Y.; Ban, I.; Harii, K. Combined therapy using Q-switched ruby laser and bleaching treatment with tretinoin and hydroquinone for periorbital skin hyperpigmentation in Asians. Plast. Reconstr. Surg. 2008, 121, 282-288. [CrossRef]

29. Corduff, N. An alternative periorbital treatment option using calcium hydroxyapatite for hyperpigmentation associated with the tear trough deformity. Plast. Reconstr. Surg. Glob. Open 2020, 8, e2633. [CrossRef]

30. Wollina, U. Improvement of tear trough by monophasic hyaluronic Acid and calcium hydroxylapatite. J. Clin. Aesthet. Dermatol. 2014, 7, 38-43.

31. Shue, S.; Kurlander, D.E.; Guyuron, B. Fat injection: A systematic review of injection volumes by facial subunit. Aesthetic Plast. Surg. 2018, 42, 1261-1270. [CrossRef]

32. Loeb, R. Naso-jugal groove leveling with fat tissue. Clin. Plast. Surg. 1993, 20, 393-400. [CrossRef]

33. Nassif, P.S. Lower blepharoplasty: Transconjunctival fat repositioning. Facial Plast. Surg. Clin. N. Am. 2005, 13, 553-559. [CrossRef]

34. Hamra, S.T. Arcus marginalis release and orbital fat preservation in midface rejuvenation. Plast. Reconstr. Surg. 1995, 96, 354-362. [CrossRef] [PubMed]

35. Jiang, J.; Wang, X.; Chen, R.; Xia, X.; Sun, S.; Hu, K. Tear trough deformity: Different types of anatomy and treatment options. Postepy Dermatol Alergol. 2016, 33, 303-308. [CrossRef]

36. Goldman, A.; Lotti, T.; Tchernev, G.; Wollina, U. Successful treatment of reticular blue veins of the lower eyelid by long-pulse Nd: YAG-Case report with 8-year follow-up. Open Access Maced. J. Med. Sci. 2017, 6, 58-60. [CrossRef] [PubMed]

37. Goldman, A.; Prati, C.; Rossato, F. Hand rejuvenation using intense pulsed light. J. Cutan. Med. Surg. 2008, 12, 107-113. [CrossRef] [PubMed] 
38. Wollina, U.; Goldman, A. Management of stretch marks (with a focus on striae rubrae). J. Cutan. Aesthet. Surg. 2017, 10, 124-129. [CrossRef]

39. Wollina, U. Hyaluronsäure in der ästhetischen Dermatologie. Praktische Erfahrungen mit einem topischen Hyaluronsäure-Serum. Kosmet. Med. 2006, 27, 16-18.

40. Colvan, L.; Fleck, T.; Vega, V.L. Global periorbital skin rejuvenation by a topical eye cream containing low molecular weight heparan sulfate (LMW-HS) and a blend of naturally derived extracts. J. Cosmet. Dermatol. 2019, 18, 530-538. [CrossRef]

41. Mendiratta, V.; Rana, S.; Jassi, R.; Chander, R. Study of causative factors and clinical patterns of periorbital pigmentation. Indian Dermatol. Online J. 2019, 10, 293-295. [CrossRef] [PubMed]

42. Wollina, U. Pre- and post-laser treatment in cosmetic dermatology. Eur. Dermatol. 2010, 5, 47-49. 